\title{
INHIBITION OF LIPID PEROXIDATION INDUCED BY ULTRAVIOLET RADIATION BY CRUDE PHLOROTANNIS ISOLATED FROM BROWN ALGAE Sargassum hystrix v. buxifolium C. Agardh
}

\author{
Agnes Nora Iska Harnita ${ }^{1, *}$, Ign. Edi Santosa ${ }^{2}$, Sudibyo Martono ${ }^{3}$, \\ Sudarsono ${ }^{3}$, Sitarina Widyarini ${ }^{4}$, and Frans J.M. Harren ${ }^{5}$ \\ ${ }^{1}$ Faculty of Pharmacy, Sanata Dharma University, Yogyakarta, Indonesia \\ ${ }^{2}$ Dept of Physics Education, Sanata Dharma University, Yogyakarta, Indonesia \\ ${ }^{3}$ Faculty of Pharmacy, Universitas Gadjah Mada, Yogyakarta, Indonesia \\ ${ }^{4}$ Faculty of Veterinary Science, Universitas Gadjah Mada, Yogyakarta, Indonesia \\ ${ }^{5}$ Life Science Trace Gas Facility, Molecular and Laser Physics, Radboud University, Nijmegen, Netherlands
}

Received November 9, 2012; Accepted March 22, 2013

\begin{abstract}
This study examines the antioxidant activity of crude phlorotannins from the brown algae Sargassum hystrix $v$. buxifolium (Chauvin) J. Agardh, through the inhibition of a lipid peroxidation reaction that is induced by the UV radiation. The antioxidant activity during the UV exposure was investigated using the laser-based photoacoustic method for the detection of the ethylene as indicator for lipid peroxidation. This involves an experiment that isolated crude phlorotannins from the ethyl acetate fraction of the Sargassum hystrix methanol extract, hereafter referred to as PFSH. It results in the antioxidant activity as a potent lipid peroxidation inhibitor. Statistically, such antioxidant activity is not significantly different than the commercial antioxidant, which is vitamin $C(p>0.05)$. The amount of the total phlorotannins, using the Folin-Ciocalteu method, was measured to be approximately $0.13 \% \mathrm{w} / \mathrm{w}$. In addition, it is found that PFSH contains phlorotannins with low molecular weight (MW) $(<1000 \mathrm{Da})$.
\end{abstract}

Keywords: phlorotannins; Sargassum hystrix; lipid peroxidation; photoacoustic; Folin Ciocalteu method

\begin{abstract}
ABSTRAK
Penelitian ini bertujuan untuk menguji aktivitas antioksidan fraksi phlorotannin alga coklat Sargassum hystrix v.buxifolium C. Agardh melalui penghambatan reaksi lipid peroksidasi akibat radiasi UV. Aktivitas antioksidan selama pemaparan UV diuji dengan metode fotoakustik berbasis laser untuk mendeteksi etilen sebagai indikator lipid peroksidasi. Penelitian ini menggunakan fraksi phlorotannin, yaitu fraksi etil asetat ekstrak metanol Sargassum hystrix, yang selanjutnya dirujuk sebagai FPSH. Hasil penelitian menunjukkan bahwa FPSH adalah inhibitor lipid peroksidasi yang potent. Secara statistik, aktivitas antioksidan FPSH tersebut tidak berbeda secara signifikan dibandingkan antioksidan komersial, yaitu vitamin $C(p>0,05)$. Kadar phlorotannin total ditentukan dengan metode Folin-Ciocalteu yaitu sebesar sekitar $0,13 \% \mathrm{~b} / \mathrm{b}$. Selain itu, penelitian ini menemukan FPSH mengandung phlorotannin dengan berat molekul (BM) rendah (<1000 Da).
\end{abstract}

Kata Kunci: phlorotannins; Sargassum hystrix; lipid peroksidasi; fotoakustik; metode Folin Ciocalteu

\section{INTRODUCTION}

The reactive oxygen species (ROS) is generated as a consequence of the ultraviolet (UV) exposure that produces oxidative stress [1]. Some ROS, including superoxide anions, hydroxyl radicals, and hydrogen peroxide, are important mediators in the initiation of the lipid peroxidation. This mainly occurs in biomembranes, where the content of unsaturated fatty acids is relatively high. This leads to the destruction of cellular membranes, and is related to the development of many chronic diseases such as aging and cancer [2-3]. Other studies have measured several markers of lipid peroxidation in the human body such as the thiobarbituric acid reactive substances (TBARS), ethylene (ethene) and pentane in the breath gas, lipid hydroperoxides, and aldehydes such as malonaldehyde (MDA) [4]. Previous study has proved that the measurement of the exhaled volatile hydrocarbons ethylene $\left(\mathrm{C}_{2} \mathrm{H}_{4}\right)$ is an on-line and non-

* Corresponding author. Tel/Fax : +62-274-883037

Email address : nora.iska@gmail.com

Agnes Nora Iska Harnita et al. 
invasive method to monitor lipid peroxidation. The ethylene as a result of the lipid peroxidation during the UV exposure of the skin has been investigated using the laser-based photoacoustic method [5-6]. The human body contains antioxidants to fight against free radicals. Examples of antioxidants are vitamins $\mathrm{A}, \mathrm{C}$, and $\mathrm{E}$, coenzyme Q10, a-lipoic acid, and glutathione [7]. Creams that contain antioxidants as the inhibitor lipid peroxidation have protective effects against the UV radiation related skin damage [1-2]. Several studies have shown that polyphenols have beneficial effects for human health, especially as antioxidants [1-2]. However, there is not enough literature or data on the presence of polyphenolic compounds as well as the antioxidant activity of various seaweeds, especially tropical [8]. The Sargassum genus, such as brown algae, has shown a high antioxidant potential in vitro [9]. Phenolic compound from the brown algae Sargassum hystrix from Yogyakarta, Indonesia, showed a high antioxidant activity in vitro [9]. The main phenolic compounds that were detected in brown algae were phlorotannins. Phlorotannins are polyphenols that are formed by the polymerization of the phloroglucinol units $(1,3,5-$ trihydroxybenzene), that can only be obtained from the brown algae (Phaeophyceae) [10-11]. Previous study screened several species of Sargassum, found in the coastal area of Gunung Kidul, Yogyakarta, Indonesia, for their sunscreens effect. The study showed that PFSH has the highest sunscreen effect among other Sargassum species [unpublished]. The goal of this study is to use the laser-based photoacoustic detection to evaluate the photoprotection capability of the ethyl acetate fraction of the brown algae, through the inhibition of the lipid peroxidation mechanism that is induced by the UV radiation. The photoprotection capability is examined by measuring the production of the ethylene that is released during the UV radiation as an indicator of the lipid peroxidation process.

\section{EXPERIMENTAL SECTION}

\section{Materials}

In this experiment, the base cream Biocream ${ }^{\circledR}$ (Manufactured by PT Merck Tbk, Jakarta under the license from Merck KgaA, Germany) was used as a control. The Biocream ${ }^{\circledast}$ is an ambiphilic dermatological cream that contains Aerosil ${ }^{\circledR}$, paraffin liquid, vaseline album, cetostearol, sorbimacrogol, palmit 300, monostearin, Miglyol ${ }^{\circledR} 812$, acid sorbic., propylenglycol, and aqua dem. Vitamin $\mathrm{C}$ (ascorbic acid) as a standard antioxidant and PFSH were mixed with Biocream ${ }^{\circledR}$ in a $2.5 \%(\mathrm{w} / \mathrm{w})$ concentration. Vitamin $\mathrm{C}$ is commercially available from Merck, Germany as a pro analysis grade.

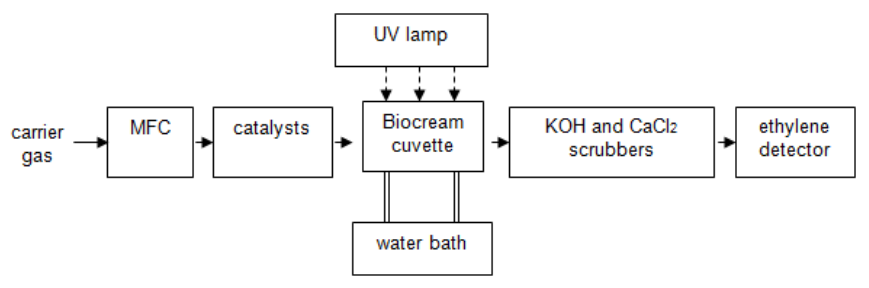

Fig 1. Experimental setup

\section{Instrumentation}

The ethylene production from Biocream ${ }^{\circledR}$ and the antioxidant creams (Vitamin $C$ and PFSH), under the exposure of the UVB and UVA radiation, was measured using a commercial ethylene detector (Sensor Sense BV, Nijmegen, the Netherlands). As a UV radiation source, a Philips original home solaria HB 405/A that contains a Philips HPA 400W UV type 3 lamp was used. The UV radiation intensity was measured using Dr Honle AG-a UV meter. The UVB and UVA radiation intensities are, respectively, $(1.6 \pm 0.1) \mathrm{mW} / \mathrm{cm}^{2}$ and $(14.3 \pm 0.4) \mathrm{mW} / \mathrm{cm}^{2}$. Fig. 1 shows the overall experimental setup.

\section{Procedure}

\section{Collection of plant material}

The brown algae Sargassum hystrix v. buxifolium (Chauvin) J. Agardh was collected from the coastal area of Gunung Kidul $\left(08^{\circ} 08^{\prime} \mathrm{N}, 110^{\circ} 34^{\prime} \mathrm{E}\right)$, Yogyakarta, Indonesia. Samples were washed with tap water to remove the epiphytes and other marine organisms. They were later dried in an oven at the temperature of $90{ }^{\circ} \mathrm{C}$, powdered, and then stored at the room temperature.

\section{Preparation of extracts}

The crude phlorotannins were extracted from the algal powder with Nagayama et. al. (12) method with several modifications. The algal powder $(200 \mathrm{~g}$, moisture < $10 \%$ ) was extracted using the methanol $(600 \mathrm{~mL})$ with shaking $(90 \mathrm{rpm})$ at the room temperature for $48 \mathrm{~h}$. The extracts were concentrated in vacuo to a small volume $(60 \mathrm{~mL})$ before adding the methanol $(60 \mathrm{~mL})$, the chloroform $(120 \mathrm{~mL})$ and the deionized water $(45 \mathrm{~mL})$. The upper and lower layers were then separated. The upper layer was extracted twice with the ethyl acetate $(75 \mathrm{~mL})$. The ethyl acetate (EtOAc) fraction was evaporated in vacuo until dry, and stored at $4{ }^{\circ} \mathrm{C}$. This fraction is hereafter referred to as PFSH.

\section{Determination of total phenolic}

The total phlorotannin concentrations were measured using the Folin Ciocalteu method. This 
assay is routinely used to quantify the level of total phenolic compounds. The ethyl acetate fraction $(0.05 \mathrm{~g})$ was dissolved in $50.0 \mathrm{~mL} 75 \%$ acetone. Five $\mathrm{mL}$ of the sample solution are pipetted and put into $50.0 \mathrm{~mL}$ volumetric flask that contains $2.5 \mathrm{~mL}$ of Folin-Ciocalteu phenol reagent $(1: 1)$. It was then diluted with distilled water and mixed thoroughly. After two minutes, $7.5 \mathrm{~mL}$ of $1.9 \mathrm{M} \mathrm{Na}_{2} \mathrm{CO}_{3}$ solution was added, mixed thoroughly with a vortex, and incubated at the room temperature for $30 \mathrm{~min}$. It then results in a blue color product. The absorbance of the blue color product was measured with a visible spectrophotometer at $750 \mathrm{~nm}$. The total phenolic content was calculated using the standard curved of phloroglucinol, and was expressed as $\mathrm{mg} \%$ of phloroglucinol equivalent (PGE) of the dry weight.

\section{Identification and characterization of low MW (Molecular Weight) phlorotannins}

A portion $(0.5 \mathrm{~g})$ of PFSH was dissolved in $4 \mathrm{~mL}$ methanol and was chromatographed, after diluting it (1:20) with acetone. The identification of PFSH was performed with a protonated molecular ions $\left([\mathrm{M}+\mathrm{H}]^{+}\right)$, compared with the corresponding compounds in the literature (refer to the Result and Discussion section below) and the ethyl acetate fraction from green tea extract. The protonated molecular ions $\left([\mathrm{M}+\mathrm{H}]^{+}\right)$at $\mathrm{m} / \mathrm{z}$ 50-200 and $\mathrm{m} / \mathrm{z}$ 100-1000 were recorded using a Electrospray Ionization (ESI) Mass Spectrometer (Thermo Finnigan). The gas liquid chromatography (GLC) was carried out using a GC-MS Polaris Q (Thermo Finnigan) in a capillary column (VF -1701MS $30 \mathrm{~m}, 0.25 \mathrm{~mm}$ i.d., $0.25 \mu \mathrm{m} \mathrm{df}$ )

\section{Inhibitory activity of lipid peroxidation of PFSH using the laser-based photoacoustic method}

Biocream ${ }^{\circledR}$ was smeared on a glass plate $(4 \mathrm{~cm}$ of diameter) over the area of $12.5 \mathrm{~cm}^{2}$, and put into the cuvette. Fig. 1 shows the experimental setup. As a carrier gas, dry air was used (free hydrocarbons especially ethylene). During the experiment, the flow rate of the carrier gas was $1.8 \mathrm{~L} / \mathrm{h}$. A mass flow controller (MFC) was used to regulate the flow rate of the carrier gas. Hydrocarbons (ethylene) were removed by flowing the gas through the catalysts. $\mathrm{KOH}$ and $\mathrm{CaCl}_{2}$ pellets were used to avoid the spectroscopic interference with the ethylene absorption lines by removing the $\mathrm{CO}_{2}$ and water vapor from the gas. The purpose of using these scrubbers ( $\mathrm{KOH}$ and $\mathrm{CaCl}_{2}$ pellets) is to obtain more accurate and sensitive measurements. The ethylene concentration in the outgoing gas flow was measured continuously every $5 \mathrm{sec}$ using the ethylene detector. For each experiment, the ethylene measurements started $5 \mathrm{~min}$ before the UV exposure $(10 \mathrm{~min})$, and ended 10 min after the exposure, to allow the complete refresh of the ventilation volume. The same procedure was used for vitamin $C$ in Biocream ${ }^{\circledR}(2.5 \% \mathrm{w} / \mathrm{w})$, and PFSH in Biocream ${ }^{\circledR}(2.5 \% \mathrm{w} / \mathrm{w})$.

\section{RESULT AND DISCUSSION}

\section{Determination of Total Phenolic}

Researchers are looking for natural antioxidants that are safe and non-toxic, especially from medicinal plants [13]. Studies have shown that marine organisms including brown algae are important sources of new bioactive compounds. The main chemical constituents of brown algae are polysaccharides and polyphenols [14]. The polyphenolic compounds from brown algae are identified as phlorotannin on Sargassum kjellamanianum which is indicated as an antioxidant [2]. The concentration of phlorotannins was measured with the modified Folin-Ciocalteu methods [15]. The colorimetric assay was based on the protocol developed by Folin and Ciocalteu that can be used to determine the concentration of soluble phenols [16]. This method relied on the reduction of the mixture of phosphotungstic $\left(\mathrm{WO}^{2-}\right)$ and phosphomolybdic $\left(\mathrm{MoO}^{2-}{ }^{2-}\right.$ reagents based on the phenolic hydroxyl group, resulting in the formation of a blue colored product. The blue colored product is proportional to the phenol content [16-17]. The total phenolic of PFSH was determined from the regression equation of the standard curve $y=0.1262 x+0.0151$, and expressed as $\mathrm{mg} \%$ of the phloroglucinol equivalents (PGE) of the dry weight. The phloroglucinol monomer was used as a standard, since they do not contain phenolic other than phlorotannins [15]. This fraction contains a total phenolic content of $(132.9 \pm 0.5) \mathrm{mg} \%$, or approximately $0.13 \%$. It is the highest among other tropical Sargassum species. In the brown algae, the low phlorotannins level can be $\leq 1 \%$, while the high level can be $>15 \%$ of the dry weight. Those levels are correlated with the taxonomy and biogeography [18]. In addition, many studies have shown that the brown algae in the tropical climates have the phenolic level which is smaller than in the subtropical climates [19]. Such smaller phenolic level is also possible due to the reduction of the phlorotannins level of the storage, the drying, the extraction or the analysis methods. It should be pointed out that the Folin-Ciocalteu method was used to measure the total phenolic content only, not individual. This method also does not discriminate different phenolic fractions with high and low molecular weight. 


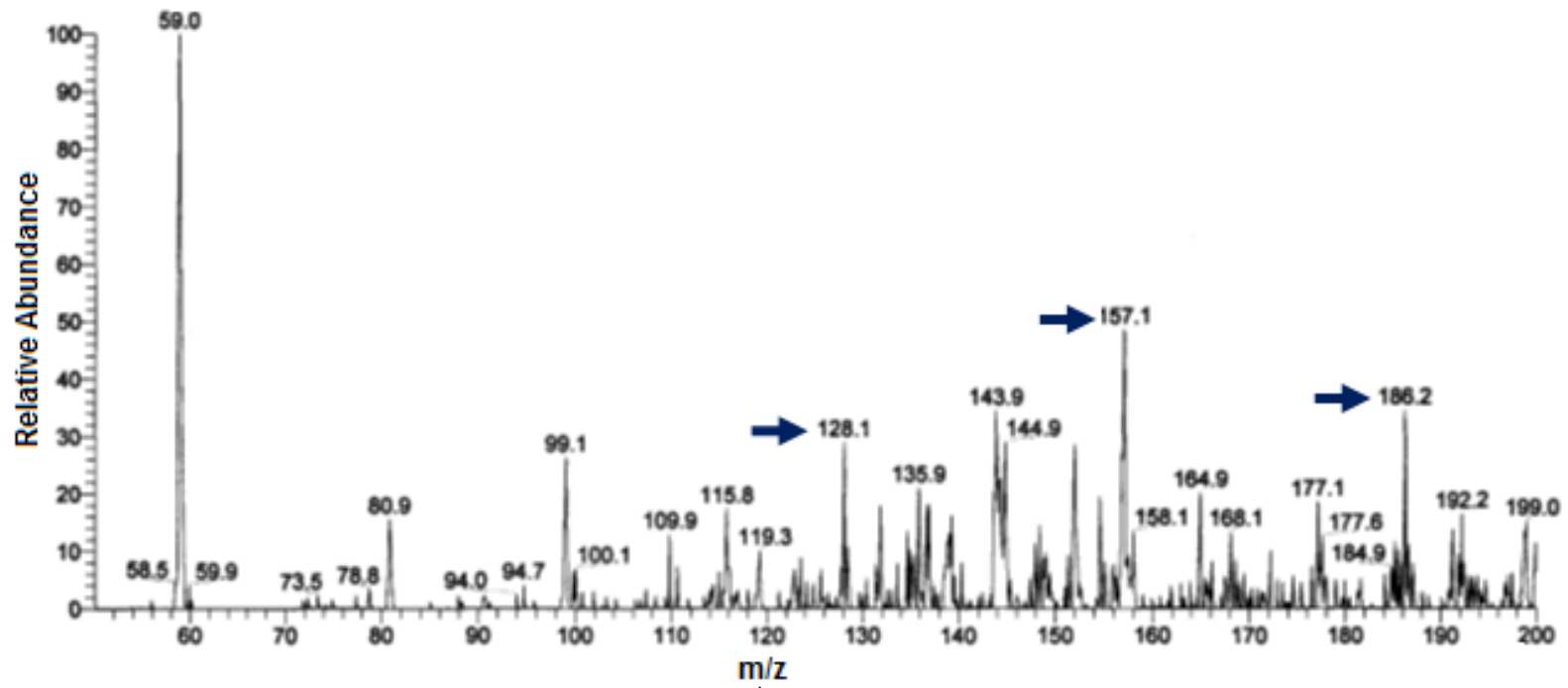

Fig 2. The protonated molecular ions $\left([\mathrm{M}+\mathrm{H}]^{+}\right)$recorded at $\mathrm{m} / \mathrm{z} 50-200$ range spectrum of PFSH

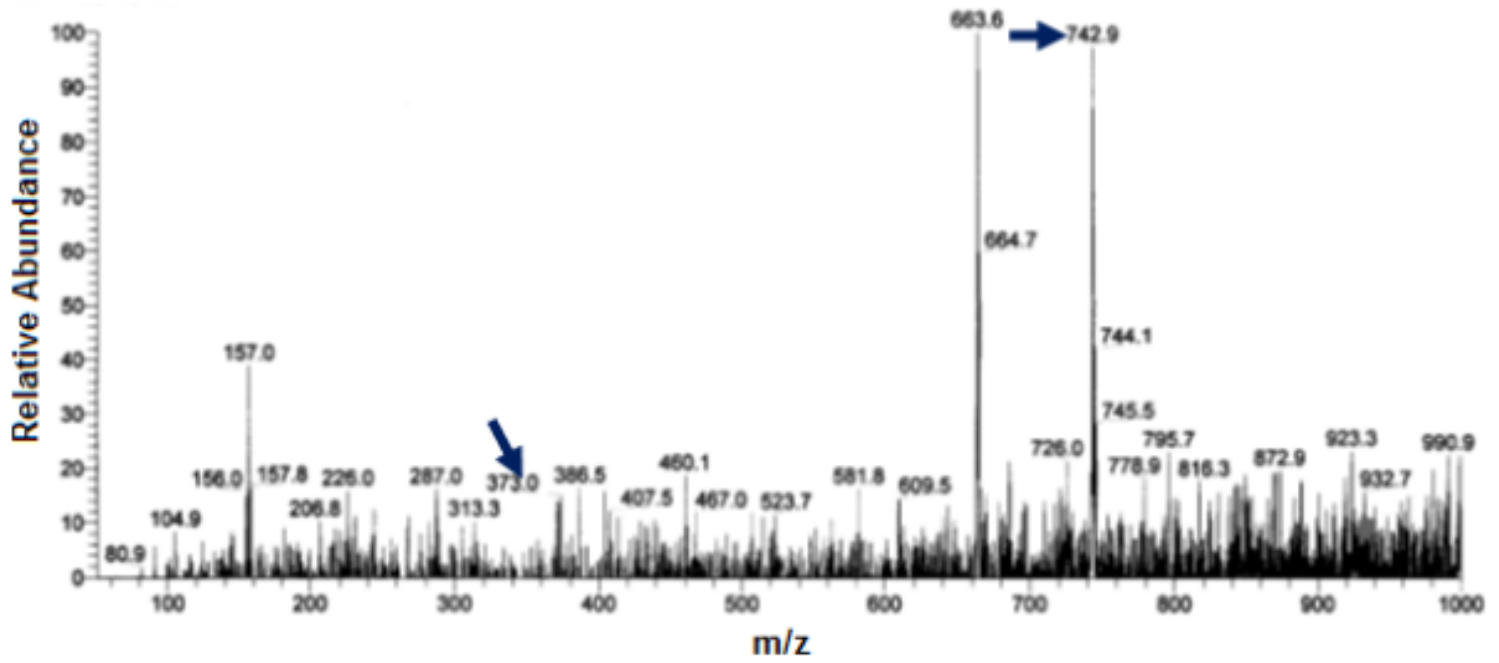

Fig 3. The protonated molecular ions $\left([\mathrm{M}+\mathrm{H}]^{+}\right)$recorded at $\mathrm{m} / \mathrm{z}$ 100-1000 range spectrum of PFSH

\section{Identification and Characterization Low MW (Molecular Weight) Phlorotannins}

In this study, the hyphenated technique of GC-ESIMS was used to analyze the chemical fingerprints for the quality control and the standardization of brown algae. The coupling of a separation technique and an on-line spectroscopic detection technology is known as hyphenated technique [20]. Several studies have identified that the ethyl acetate fraction of several species of brown algae contain phlorotannins from the phloroglucinol (monomer) until phlorotannins (oligomer). The examples of phlorotannins oligomer are eckol (trimer), phlorofucofuroeckol A (pentamer), dieckol (hexamer), and 8.8 '-bieckol (hexamer) [12-13,21-22]. This study used the protonated molecular ion $\left([\mathrm{M}+\mathrm{H}]^{+}\right)$. The mass spectra of various components that are present in PFSH has been obtained on-line from the GC-
ESI-MS run (tracing $\mathrm{m} / \mathrm{z}$ of $50-200$ range and 100-1000 range). Based on the MS data, it is proven that PFSH contains phlorotannins with low molecular weight $(\mathrm{MW})(<1000 \mathrm{Da})$. A peak at $\mathrm{m} / \mathrm{z} 128\left([\mathrm{M}+\mathrm{H}]^{+}\right)$ was thought to be phlorotannins composed by one phloroglucinol unit (monomer) (Fig. 2). Also identified are two other peaks that correspond to the phloroglucinol at $\mathrm{m} / \mathrm{z} 157$ and $\mathrm{m} / \mathrm{z} 186$, indicating the acetylated phloroglucinol derivatives (the additional acetyl group with MW 29). A peak at $\mathrm{m} / \mathrm{z} 373\left([\mathrm{M}+\mathrm{H}]^{+}\right)$ was identified as oligomer with three phloroglucinol units (trimer) (Fig. 3). Protonated molecular ion at $\mathrm{m} / \mathrm{z} 743$ is suggested to be a polyphenolic compound composed by six phloroglucinol units (hexamer), which is supported by studies by Myung et al. [14] and Kang et al. [21]. Hereafter, these five peaks $(\mathrm{m} / \mathrm{z} 128$, $\mathrm{m} / \mathrm{z} 157, \mathrm{~m} / \mathrm{z} 186, \mathrm{~m} / \mathrm{z} 373$ and $\mathrm{m} / \mathrm{z}$ 743) were compared with the known standards for the chemical 


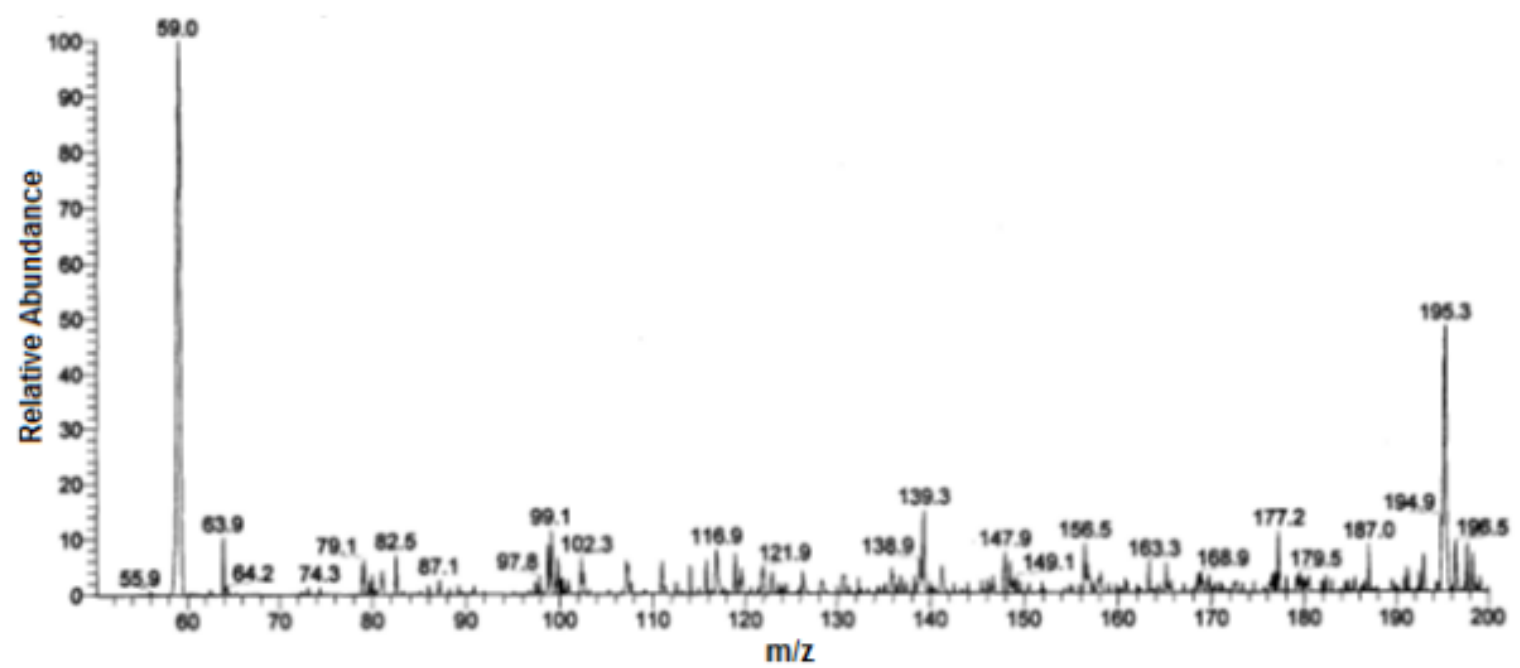

Fig 4. The protonated molecular ions $\left([\mathrm{M}+\mathrm{H}]^{+}\right)$recorded at $\mathrm{m} / \mathrm{z} 50-200$ range spectrum of the ethyl acetate fraction from green tea extract

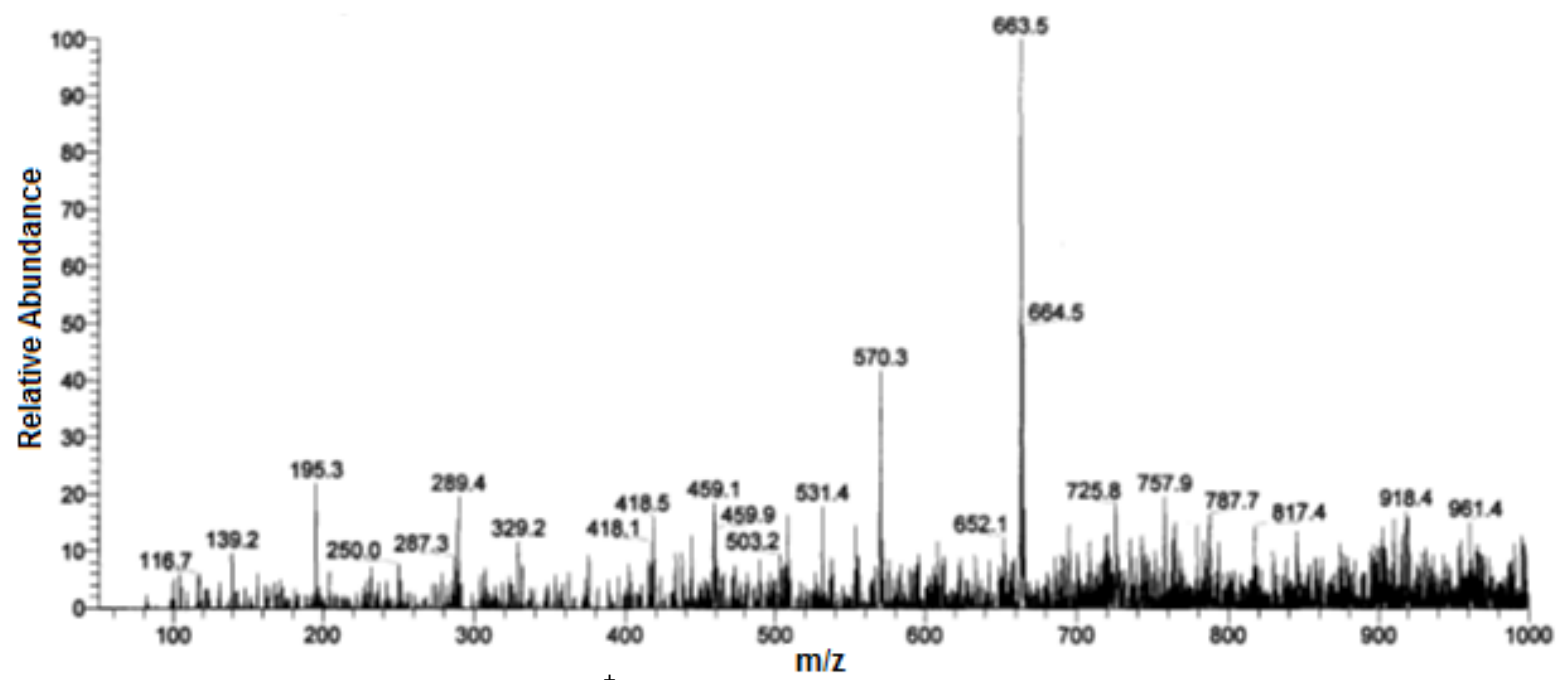

Fig 5. The protonated molecular ions $\left([\mathrm{M}+\mathrm{H}]^{+}\right)$recorded at $\mathrm{m} / \mathrm{z} 100-1000$ range spectrum of the ethyl acetate fraction from green tea extract

fingerprint confirmation of the ethyl acetate fraction of the green tea extract. It results in these four peaks that are not present in the ethyl acetate fraction of the green tea extract as terrestrial polyphenols (Fig. 4 and 5). Therefore, these five peaks can be used as marker compounds of phlorotannins brown algae (as marine polyphenols). This result is supported by previous studies, in which the chemical structure of terrestrial polyphenol has a different structure than the phlorotannins as marine polyphenol [11,23-24].

\section{Inhibitory Activity of Lipid Peroxidation using the Laser-Based Photoacoustic Method}

It is well known that the oxidative stress, especially the exposure of the UV radiation, causes lipid peroxidation and cellular damages to the skin [25]. Lipid membranes are highly susceptible to injury by the UV radiation. In this process, ROS and free radicals are produced and act directly on lipids, inducing oxidative damages on tissues or cells. The increase in lipid peroxidation products associated with the harmful effects of the collapse of the cell membranes and the cell organelles initiated the release of lipid peroxidation products that may also result in DNA damages [1,26]. Many types of antioxidants are able to respond directly to and eliminate free radicals, and are therefore called radical-scavenging antioxidants. These are divided into water-soluble antioxidants, such as vitamin $\mathrm{C}$ or ascorbic acid, and fat-soluble antioxidants, such as vitamins $A$ and $E$ as well as coenzyme Q10 [7]. Therefore, vitamin $C$ was used as a standard antioxidant to prevent the oxidative damages to macromolecules, including lipids. It is known that the 


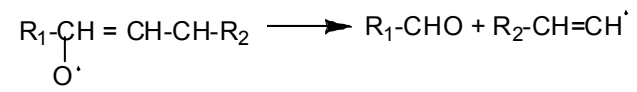

(Lipid hydroperoxyde) (aldehyde Ester) (hydrocarbon end such as ethylene)

Fig 6. Reaction of the volatile decomposition compounds from the secondary lipid oxidation products [27]

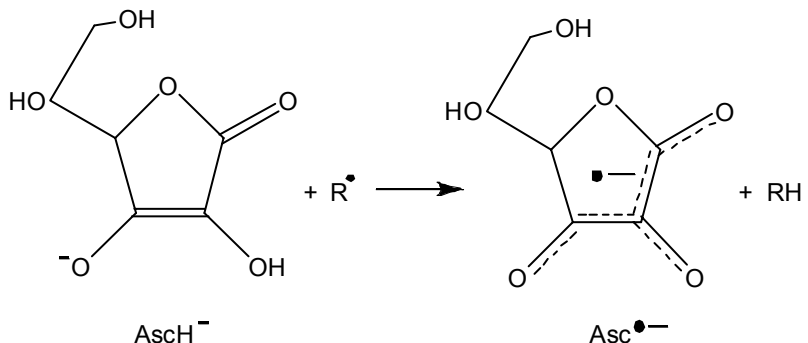

Fig 7. Antioxidant mechanism of ascorbic acid (vitamin C) as free radical scavenger

$$
\mathrm{PhOH}+\mathrm{R}^{\bullet} \longrightarrow \mathrm{PhO}^{\circ}+\mathrm{RH}
$$

Fig 8. Antioxidant mechanism of polyphenol as free radical scavenger

lipid peroxidation process produces a variety of hydrocarbon gases such as ethylene (see Fig. 6) [2728].

The ethylene product of lipid peroxidation in the skin during the UV exposure was examined using the laser-based photoacoustic method [5-6,29-30]. The total ethylene production depends on the amount of lipids that are attacked by ROS. The total ethylene production in a Biocream $^{\circledR}$ that is a result of the UV radiation is $(12.3 \pm$ 3.0) $\mathrm{nL} / \mathrm{g}$ as a control. The lowest ethylene production that is generated by the UV radiation at $2.5 \% \mathrm{w} / \mathrm{w}$ vitamin $C$ in Biocream $^{R}$ is $(2.45 \pm 0.87) \mathrm{nL} / \mathrm{g}$. This result is supported by the theory that the vitamin $\mathrm{C}$ (mostly in a biological system as ascorbic anion) is a very efficient "free radical scavenger" because it has very active hydroxyl groups (see Fig. 7) [31].

PFSH protects lipids from the peroxidation damage induced by the UV radiation, as demonstrated by the decrease level of the ethylene production. This study demonstrated that the PFSH in Biocream ${ }^{\circledR}$ can produce the total ethylene of $(2.5 \pm 1.60) \mathrm{nL} / \mathrm{g}$. This study was confirmed by ESI-MS, in which PFSH contains phlorotannins with low MW, in the form of a monomer, a trimer and a hexamer. According to t-test statistical analysis, there are no significant differences $(p>0.05)$ in total ethylene production between PFSH and the vitamin $\mathrm{C}$ as a standard antioxidant. Phlorotannins have a polyphenol structure. Polyphenols are electron-rich compounds that prone to enter into efficient electrondonation reactions with oxidizing agents to produce phenoxyl radical $(\mathrm{PhO} \cdot)$ species as intermediates (see Fig. 8) [32].

In general, the criteria to enhancing the antioxidant activity of phenolic compound depends on the chemical structures, such as the substitution pattern of hydroxyl groups and the expanded conjugation system after the hydrogen or electron donation to the radicals. The presence and availability of the phenolic hydrogen and the resulting stabilization from the electron delocalization enhances the antioxidant activity [33-34]. Otherwise, PFSH also has the sunscreen effect (the ability to absorb UV B and UV A radiations). This study shows the contribution of the sunscreen effect from the inhibitory activity of the lipid peroxidation of the ethyl acetate fraction.

\section{CONCLUSION}

In this study, the capability of PFSH in reducing the total ethylene production is shown to be comparable to vitamin $\mathrm{C}$ as the standard antioxidant. The present findings are useful for the further development of this fraction as the primary candidate of the photoprotection agent of the oxidative damage to the DNA.

\section{ACKNOWLEDGEMENT}

The authors wish to thank to Sacco te Lintel Hekkert for providing the ethylene detector, Cor Sikkens for his expertise in technical assistance. The financial support provided by the KNAW (The Royal Dutch Academy of Science and Art).

\section{REFERENCES}

1. Katiyar, S.K., Afaq, F., Perez, A., and Mukhtar, H., 2001, Carcinogenesis, 22, 2, 287-294.

2. Lim, S.N., Cheung, P.C.K., Ooi, V.E.C., and Ang, P.O., 2002, J. Agric. Food Chem., 50, 13, 38623866.

3. Kang K.A., Zhang, R., Lee, K.H., Chae, S., Kim, B.J., Kwak, Y.S., Park, J.W., Lee, N.H., and Hyun, J.W., 2006, J. Radiat. Res., 47, 1, 61-68.

4. Niki, E., 2008, BioFactors, 34, 171-180.

5. Harren, J.M., Berkelmans, R., Kuiper, K., te Lintel Hekkert, S., Scheepers, P., Dekhuijzen, R., Hollander, P., and Parker, D.H., 1999, Appl. Phys. Lett., 74, 12, 1761-1763.

6. Cristescu, S., Berkelmans, R., te Lintel Hekkert, S., Timmerman, B., Parker, D., and Harren, F., 2000, Proc. SPIE, 4162, 101-105.

7. Naito, Y., Lee, M.C., Kato, Y., Nagai, R., and Yonei, Y., 2010, Anti-Aging Med., 7, 5, 36-44.

8. Santoso, J., Yoshie-Stark, Y., and Suzuki, T., 2004, Fish. Sci., 70, 1, 183-188.

9. Budhiyanti, S.A., Raharjo, S., Marseno, D.W., and Lelana, I.Y.B., 2011, J. Biol. Sci., 11, 4, 288-298. 
10. Koivikko, R., Loponen, J., Honkanen, T., and Jormalainen, V., 2005, J. Chem. Ecol., 31, 1, 195212.

11. Koivikko, R., Eränen, J.K., Loponen, J., and Jormalainen, V., 2008, J. Chem. Ecol., 34, 1, 57-64.

12. Nagayama, K., Iwamura, Y., Shibata, T., Hirayama, I., and Nakamura, T., 2002, J. Antimicrob. Chemother., 50, 6, 889-893.

13. Kang, H.S., Chung, H.Y., Kim, J.Y., Son, B.W., Jung, H.A., and Choi, J.S., 2004, Arch. Pharm. Res., 27, 2, 194-198.

14. Myung, C.S., Shin, H.C., Bao, H.Y., Yeo, S.J., Lee, B.H., and Kang, J.S., 2005, Arch. Pharm. Res., 28,6, 691-698.

15. Koivikko, R. 2008, Brown Algal Phlorotannins : Improving and Applying Chemical Methods, University of Turku, Turku, Finland, 1-61

16. Vermerris,W., and Nicholson, R. 2006, Phenolic Compound Biochemistry, Springer, Dordrecht.

17. Singleton, V.L., and Rossi, J.A.,Jr., 1965, Am. J. Enol. Vitic, 16, 3, 144-158.

18. Pavia,H., Toth, G.B., Lindgren, A., and Aberg, P., 2003, Phycologia, 42, 4, 378-383.

19. Targett, N.M., Boettcher, A.A., Targett, T.E., and Vrolijk, N.H., 1995, Oecologia, 103, 170-179.

20. Sarker, S.D., Latif, Z., Gray, A.I., and Nahar, L., 2006, Methods in Biotechnology: Natural Product Isolation, $2^{\text {nd }}$ ed., 257.

21. Kang, H.S., Chung, H.Y., Jung, J.H., Son, B.W., and Choi, J.S., 2003, Chem. Pharm. Bull., 51, 8, 10121014.

22. Kim, Y.C., An, R.B., Yoon, N.Y., Nam, T.J., and Choi, J.S., 2005, Arch. Pharm. Res., 28, 12, 13761380.

23. Mclnnes, A.G., Ragan, M.A., Smith, D.G., and Walter, J.A., 1984, Hydrobiologia, 116-117, 1, 597602.
24. Shibata, T., Yamaguchi, K., Nagayama, K., Kawaguchi, S., and Nakamura, T., 2002, Eur. J. Phycol., 37, 4, 493-500.

25. Someya, K., Shimizu, H., Uchiyama, C., Nakajima, I., Hayashi, T., Takada, K., Kuroyanagi, M., and Miyazawa, T., 2003, J. Oleo. Sci., 52, 9, 463-470.

26. Mittal, A., Elmets, C.A., and Katiyar, S.K., 2003, Carcinogenesis, 24, 8, 1379-1388.

27. Frankel, E.N. 1984, J. Am. Oil. Chem. Soc., 61, 12, 1908-1917.

28. Halliwell, B. and Gutteridge, J.M.C., 1999, Free Radicals in Biology and Medicine, Oxford University Press, Inc., New York, 529-535.

29. te Lintel Hekkert, S., Berkelmans, R., Kuijper, K., Scheepers, P., Hollander, P., Harren F.J.M., and Parker, D.H., 1998, On-Line, Laser-Based Setection of Ethene in Exhaled Air as Indicator for UV Induced Skin Dammage, Proc. Eur. UV Sunfilters Conf., 36-39.

30. Timmerman, B.H., Berkelmans, R., Cristescu, S., te Lintel Hekkert, S., de Gruijl, F., Meijers, M., Harren F.J.M., Gerritsen, R and Parker, D.H., 1999, In-vivo Studies of UV Effects in Human Skin Using Photoacoustics, Proc. Eur. UV Sunfilters Conf., 19-25.

31. Denisov and Afanas'ev, I.B. 2005, Oxidation an Antioxidants in Organic Chemistry and Biology, CRC Press, Taylor \& Francis, New York, 855-858.

32. Kang, K.A., Lee, K.H., Chae, S., Zhang, R., Jung, M.S., Ham, M.Y., Baik, J.S., Lee, N.H., and Hyun, J.W., 2006, J. Cell. Biochem., 97, 3, 609-620.

33. Piao, M.J., Lee, N.H., Chae, S., and Hyun, J.W., 2012, Biol. Pharm. Bull., 35, 6, 873-880.

34. Kim, H.S., Lee, K., Kang, K.A., Lee, N.H., Hyun, J.W. and Kim, H-S., 2012, J. Pharmacol. Sci., 119, 186-192. 